\title{
Simulasi Proses Bisnis Pondok Pesantren Menggunakan Anylogic Berdasarkan Metode Business Process Improvement (BPI)
}

\author{
Nikmatur Rizqi' ${ }^{1}$, Ulfa Hidayati², Teguh Arief Ramadhan ${ }^{3}$, M. Ainul Yaqin ${ }^{4}$ \\ 1,2,3,4Teknik Informatika, UIN Maulana Malik Ibrahim Malang \\ Jl. Gajayana 50 Malang 65144, Telp: (0341) 551354 \\ 116650067@student.uin-malang.ac.id, 216650068@student.uin-malang.ac.id, \\ 316650088@student.uin-malang.ac.id, ‘yaqinov@ti.uin-malang.ac.id
}

\begin{abstract}
Islamic boarding schools are traditional Islamic educational institutions in which religious values are taught as guidelines to be applied in everyday life. Islamic boarding schools are also analogous to enterprise in which there must be a business process to achieve the objectives of the establishment of boarding schools themselves. The design of business processes in Islamic boarding schools may be able to produce the desired results but sometimes it is not in accordance with the desired costs or desired time. These problems can be overcome by running a business process simulation, which aims to help the analysis and understanding of business process models. Anylogic is used in this study to simulate the boarding school business processes and use the Business Process Improvement (BPI) method to analyze problems in business processes and methods BPMN (Business Process and Notation Model) as a tool to describe or create business process flow models in graphical form.
\end{abstract}

Keywords: Anylogic, BPI, Business Process, Islamic Boarding School, Simulation.

\begin{abstract}
Abstrak
Pondok pesantren merupakan lembaga pendidikan Islam tradisional dimana di dalamnya diajarkan nilai-nilai agama sebagai pedoman untuk diterapkan dalam kehidupan sehari-hari. Pondok pesantren juga dianalogikan sebagai enterprise dimana di dalamnya pasti terdapat proses bisnis untuk mencapai tujuan dari didirikannya pondok pesantren itu sendiri. Rancangan proses bisnis yang ada dalam pondok pesantren mungkin dapat memberikan hasil yang diinginkan tapi terkadang tidak sesuai dengan biaya yang diinginkan atau waktu yang diinginkan. Masalah tersebut dapat diatasi dengan menjalankan simulasi proses bisnis, yang bertujuan untuk membantu analisis dan pemahaman tentang model proses bisnis. Anylogic digunakan dalam penelitian ini untuk mensimulasikan proses bisnis pondok pesantren dan menggunakan metode Peningkatan Proses Bisnis (BPI) untuk menganalisis permasalahan pada proses bisnis dan metode BPMN (Model Proses Bisnis dan Notasi) sebagai alat untuk menggambarkan atau membuat model alur proses bisnis dalam bentuk grafis.
\end{abstract}

Kata kunci: Anylogic, BPI, BPMN, Proses Bisnis, Pondok Pesantren, Simulasi.

\section{PENDAHULUAN}

Pondok pesantren merupakan lembaga pendidikan tradisional Islam tertua di Indonesia dimana di dalamnya diajarkan moral dan nilai-nilai agama dalam kehidupan sehari-hari. Menurut [1] mendefinisikan bahwa pondok pesantren adalah lembaga keagamaan yang memberikan pendidikan dan pengajaran serta mengembangkan dan menyebarkan ilmu agama Islam. Pondok pesantren juga dianalogikan sebagai enterprise dimana di dalamnya pasti terdapat proses bisnis untuk mencapai tujuan dari didirikannya pondok pesantren itu sendiri. Dalam melakukan seluruh kegiatan yang terdapat dalam pondok pesantren, suatu pondok 
pesantren pasti memiliki proses bisnis yang harus dijalankan yang terbagi dalam beberapa departemen. Departemen tersebut mempunyai tugas masing-masing sehingga dapat membantu mewujudkan tujuan dari pondok pesantren itu sendiri.

Dalam proses bisnis pondok pesantren, pemilik bertanggung jawab terhadap kinerja dan pengembangan dari setiap proses yang saling berhubungan. Rancangan proses bisnis yang ada dalam pondok pesantren mungkin dapat memberikan hasil yang diinginkan tapi terkadang tidak sesuai dengan biaya yang diinginkan atau waktu yang diinginkan. Masalah tersebut dapat diatasi dengan menjalankan simulasi proses bisnis, yang bertujuan untuk membantu analisis dan pemahaman tentang model proses bisnis. Menurut [2] simulasi merupakan sebuah replikasi atau visualisasi dari perilaku sebuah sistem yang berjalan pada kurun waktu yang tertentu. Jadi dapat dikatakan bahwa simulasi itu adalah sebuah model yang berisi seperangkat variabel yang menampilkan ciri utama dari sistem kehidupan yang sebenarnya. Modelling dengan simulasi berhubungan erat satu sama lain. Dengan adanya simulasi, ciri utama yang ditampilkan tersebut dapat dimodifikasi secara nyata dengan modelling.

Dalam sebuah pondok pesantren permasalahan yang sering terjadi adalah masalah penyediaan dan persiapan makanan dan minuman. Persediaan dan persiapan haruslah sesuai dengan banyaknya santri yang terdapat dalam pondok pesantren tersebut. Sehingga dapat disesuaikan kebutuhan bahan makanan yang harus disediakan dan waktu yang diperlukan untuk menyediakan makanan tersebut. Untuk itu diperlukan adanya simulasi proses bisnis pada kegiatan tersebut. Simulasi proses bisnis (BPS) dianggap sebagai alat yang kuat untuk membantu dalam analisis perubahan dan evaluasi efektivitas karena kemampuannya untuk mengukur kinerja, menguji alternatif dan terlibat dalam proses [3]. Simulasi proses bisnis juga dapat membantu dalam proses evaluasi performa sebuah model proses bisnis dengan konfigurasi yang berbeda dan dengan waktu real time. Simulasi proses bisnis ini diharapkan dapat meminimalisir kegagalan proses yang terjadi dalam memenuhi spesifikasi dan kebutuhan makanan yang telah ditentukan serta mencegah kekurangan atau kelebihan dalam penggunaan sumber daya yang ada..

\section{METODOLOGI PENELITIAN}

Metode Business Proccess Improvement (BPI) digunakan dalam penelitian ini untuk menganalisis permasalahan yang ada dalam suatu proses bisnis untuk selanjutnya dapat membantu organisasi dalam membuat kemajuan dalam proses bisnisnya. Metode BPMN (Business Process Model and Notation) juga digunakan sebagai alat untuk menggambarkan atau membuat model grafis dari operasi bisnis dimana terdapat aktifitas-aktifitas dan kontrol-kontrol alur yang mendefinisikan urutan kerja. Menurut [4], terdapat 5 fase dalam BPI yang ditunjukkan pada Gambar 1. 


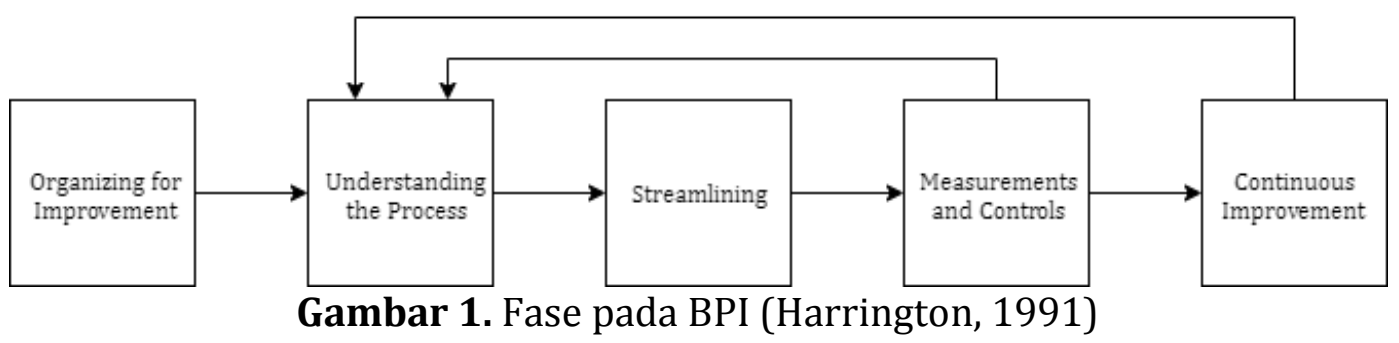

1. Organizing for Improvement yang bertujuan untuk menentukan proses bisnis mana yang harus diperbaiki dengan menggunakan pendekatan BPI.

2. Understanding the Process, dimana dilakukan pemahaman proses bisnis dengan cara menganalisis dan mendefiniskan sluruh proses yang ada untuk selanjutnya membuat proses bisnis dan dilakukan analisis waktu proses.

3. Streamlining yang merupakan inisialisasi perubahan proses bisnis menjadi lebih sederhana karena dalam fase ini dilakukan penyederhanaan proses bisnis yang bertujuan memperbaiki efektifitas, efisiensi dan adaptibilitas dari proses bisnis tersebut.

4. Measurement and Controls yang bertujuan untuk mengimplementasikan proses yang telah diperbaiki dan mengontrol proses perbaikan secara berkelanjutan.

5. Continuous Improvement yang bertujuan untuk menerapkan proses bisnis dan mengimplementasikan perbaikannya secara berkelanjutan.

Fase yang digunakan dalam penelitian ini hanya mencakup Organizing for Improvement dan Understanding the Process untuk selanjutnya digunakan dalam proses simulasi dengan menggunakan Anylogic

\section{HASIL DAN PEMBAHASAN}

Dalam melakukan seluruh kegiatan yang terdapat dalam pondok pesantren, suatu pondok pesantren pasti memiliki proses bisnis yang harus dijalankan yang terbagi dalam beberapa departemen. Departemen tersebut mempunyai tugas masing-masing sehingga dapat membantu mewujudkan tujuan dari pondok pesantren itu sendiri. Departement for Education United Kingdom merilis national minimum standart for Boarding school pada tahun 2015 dimana terdapat 20 Standar yang harus terpenuhi untuk pondok pesantren, diantaranya:

Standar 1 - Pernyataan prinsip dan praktik asrama

Standar 2 - Induksi dan dukungan asrama

Standar 3 - Kesehatan dan kesejahteraan asrama

Standar 4 - Kontak dengan orang tua / pengasuh

Standar 5 - Akomodasi asrama

Standar 6 - Keselamatan asrama

Standar 7 - Pencegahan kebakaran dan latihan

Standar 8 - Penyediaan dan persiapan makanan dan minuman

Standar 9 - Kepemilikan asrama

Standar 10 - Kegiatan dan waktu luang 
http://tunasbangsa.ac.id/ejurnal/index.php/jurasik

Standar 11 - Perlindungan anak

Standar 12 - Mempromosikan perilaku dan hubungan positif

Standar 13 - Manajemen dan pengembangan asrama

Standar 14 - Perekrutan dan pemeriksaan staf pada orang dewasa lainnya

Standar 15 - Penetapan Staf dan pengawasan

Standar 16 - Kesempatan yang setara

Standar 17 - Mengamankan pandangan asrama

Standar 18 - Keluhan

Standar 19 - Prefek

Standard 20 - Lodgings (tinggal lama)

Dalam penelitian ini penulis mensimulasikan proses bisnis yang terdapat pada Standar 8 mengenai penyediaan dan persiapan makanan dan minuman dengan menggunakan Anylogic.

\subsection{Analisis Proses Bisnis}

Berikut ini merupakan alur proses bisnis pondok pesantren pada Standart 8 Penyediaan dan persiapan makanan dan minuman :

a) Petugas dapur membeli bahan masakan dan minuman

b) Bahan masakan akan di stok dan di simpan di storage (tempat penyimpanan) sebelum dimasak

c) Bahan masakan masuk ke dapur

d) Bahan masakan di olah oleh petugas dapur

e) Makanan disajikan

f) Santri menuju tempat penyajian makanan

g) Santri memakan masakan yang telah disajikan

h) Santri selesai makan lalu meninggalkan tempat

\subsection{Analisis Permasalahan pada Proses Bisnis}

Dari alur model proses bisnis pada Standar 8, maka akan menemukan permasalahan-permasalahan yang terjadi didalam proses bisnis, yaitu:

Tabel 1. Permasalahan pada proses bisnis pada standar 8 : Penyediaan dan persiapan makanan dan minuman

\begin{tabular}{|l|l|l|}
\hline \multirow{2}{*}{ No } & \multicolumn{2}{|c|}{ Proses Bisnis Pondok Pesantren } \\
\cline { 2 - 3 } & \multicolumn{1}{|c|}{ Permasalahan } & \multicolumn{1}{c|}{ Resiko } \\
\hline 1 & $\begin{array}{l}\text { Kurangnya waktu makan santri dan lamanya waktu } \\
\text { tunggu santri untuk mendapatkan makanan }\end{array}$ & $\begin{array}{l}\text { Banyak santri yang tidak makan } \\
\text { dan makanan sisa terbuang }\end{array}$ \\
\hline 2 & Lamanya bahan datang & Mundurnya waktu memasak \\
\hline 3 & Lamanya waktu memasak & Waktu makan santri berkurang \\
\hline
\end{tabular}

\subsection{Implementasi Metode BPI \\ a. Organizing for Improvement}

Tujuan dari fase ini adalah untuk menentukan proses bisnis mana yang perlu dilakukan perbaikan. Berdasarkan analisis permasalahan sebelumnya, maka 
diperoleh rekomendasi perbaikan proses bisnis, yaitu dengan menambah jumlah pekerja baik angkut maupun juru masak.

Tabel 2. Rekomendasi perbaikan pada proses bisnis

\begin{tabular}{|c|c|c|c|}
\hline \multirow[t]{2}{*}{ No } & \multicolumn{3}{|c|}{ Proses Bisnis Pondok Pesantren } \\
\hline & Permasalahan & Teknik Perbaikan & Keterangan \\
\hline 1 & $\begin{array}{lr}\text { Kurangnya } & \text { waktu } \\
\text { makan santri dan } \\
\text { lamanya } & \text { waktu } \\
\text { tunggu santri } & \text { untuk } \\
\text { mendapatkan } & \\
\text { makanan } & \\
\end{array}$ & $\begin{array}{l}\text { Menambah jumlah } \\
\text { pekerja }\end{array}$ & $\begin{array}{l}\text { Dengan menambah } \\
\text { jumlah pekerja angkut } \\
\text { dapat menambah waktu } \\
\text { makan santri tanpa } \\
\text { harus lama menunggu. }\end{array}$ \\
\hline 2 & $\begin{array}{ll}\text { Lamanya } & \text { bahan } \\
\text { datang } & \end{array}$ & $\begin{array}{l}\text { Menambah } \\
\text { angkut }\end{array}$ & $\begin{array}{lr}\text { Dapat } & \text { mengurangi } \\
\text { mundurnya } & \text { waktu } \\
\text { memasak } & \\
\end{array}$ \\
\hline 3 & $\begin{array}{l}\text { Lamanya } \\
\text { memasak }\end{array}$ & $\begin{array}{l}\text { Mengoptimalkan } \\
\text { jumlah } \\
\text { pekerja/menambah } \\
\text { jumlah pekerja }\end{array}$ & $\begin{array}{l}\text { Dapat mempercepat } \\
\text { waktu memasak }\end{array}$ \\
\hline
\end{tabular}

\section{b. Understanding the Process}

Bertujuan untuk memahami proses bisnis yang berjalan dengan mendefinisikan, menganalisis dan membuat model proses bisnis tersebut. Berikut merupakan model proses bisnis pondok pesantren dari standar 8 yaitu Penyediaan dan persiapan makanan dan minuman.

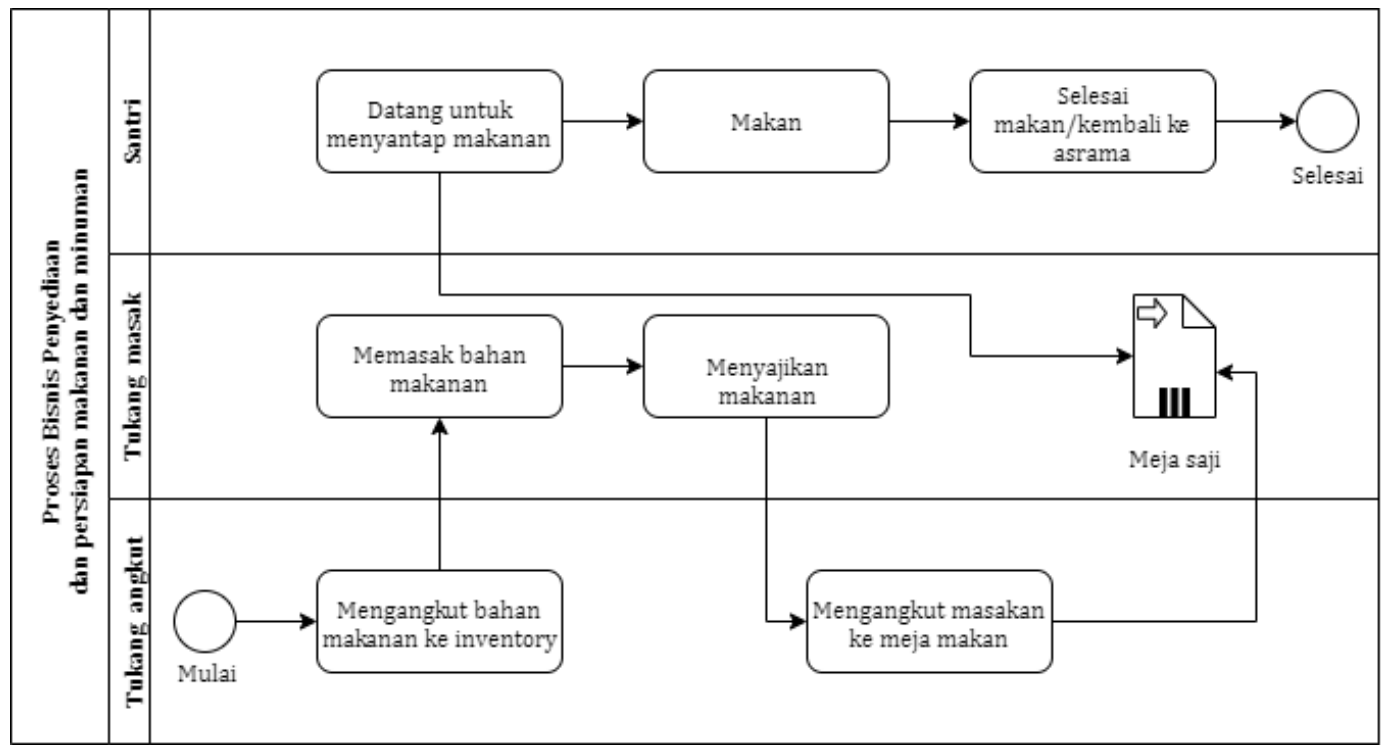

Gambar 2. Diagram alur proses bisnis

\subsection{Penerapan Simulasi pada Anylogic}

Anylogic digunakan untuk mensimulasikan proses bisnis pondok pesantren dari Standar 8 : Penyediaan dan persiapan makanan dan minuman. Berikut ini 
adalah penerapan Proses bisnis pondok pesantren Standar 8 - Penyediaan dan persiapan makanan dan minuman:

a. Resource Pool yang terdapat dalam proses bisnis Standar 8

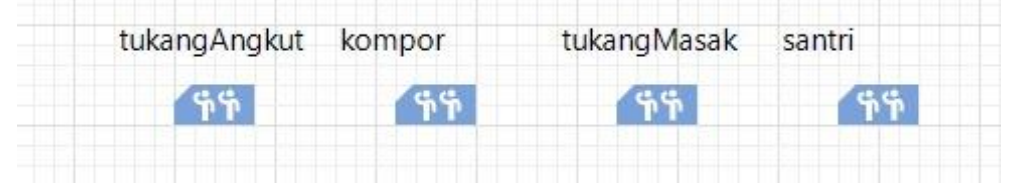

Gambar 3. Resource pool

Terdapat 4 Resource Pool diantaranya:

1) Tukang angkut : bertugas mengangkut bahan makanan yang datang dari truk untuk disimpan dalam inventory

2) Kompor : digunakan untuk memasak bahan makanan

3) Tukang masak : bertugas memasak bahan makanan yang telah disediakan

4) Santri : merupakan entitas proses bisnis yang mana tugasnya disini adalah mengambil dan memakan masakan yang telah disajikan

\section{b. Proses penyediaan dan persiapan makanan dan minuman}

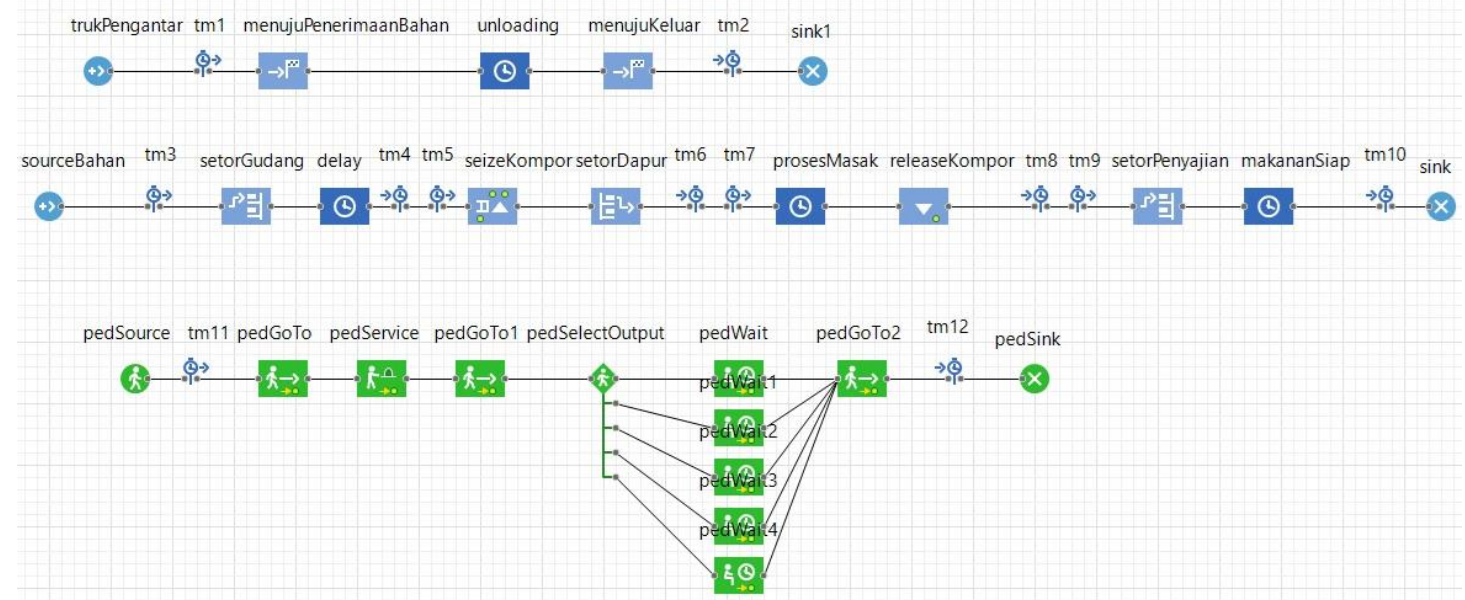

Gambar 4. Proses penyediaan dan persiapan makanan dan minuman pada Anylogic

Dimulai dengan proses pengantaran bahan makanan menggunakan truk (proses pertama) melalui proses pengantaran menuju tempat penerimaan bahan masakan. Dimana Unloading adalah proses menunggu disaat barang yang terdapat di truk diturunkan sampai selesai dan Sink merupakan tanda bahwa proses pengantaran barang telah selesai. Dilanjutkan dengan proses inventory dan proses memasak lalu penyajian (proses kedua). Dimana:

1) Source Bahan - Setor gudang merupakan proses mengangkut bahan masakan ke inventory/kulkas.

2) Seize kompor adalah dimana kompor yang ada terbatas dan penggunaan kompor dilakukan secara bergantian. 
3) Setor dapur merupakan proses bahan masakan yang di bawa ke dapur untuk selanjutnya di olah.

4) Lalu dilanjut proses masak bahan masakan.

5) Release kompor adalah apabila kompor selesai digunakan sehingga dapat digunakan kembali untuk memasak.

6) Setor penyajian merupakan proses dimana bahan masakan yang telah dimasak siap disajikan dan dibawa ke tempat penyajian.

7) Sink adalah tanda berakhirnya proses memasak apabila bahan masakan telah dimasak semua.

Proses selanjutnya dari bagan paling bawah merupakan proses antrian Santri dalam mengambil dan memakan makanan yang telah disajikan. Dengan terdapat 5 meja yang dapat digunakan santri sebagai tempat makan (ditunjukkan dengan adanya pedWait pada proses dalam Anylogic tersebut).

Berikut merupakan hasil simulasi berdasarkan dari analisis permasalahan dan teknik perbaikan proses bisnis yang ada pada tabel 2 .

c. Kondisi 1: Apabila terdapat 1 tukang angkut dan 1 juru masak

Metrics

Time in jobshop by category, minutes

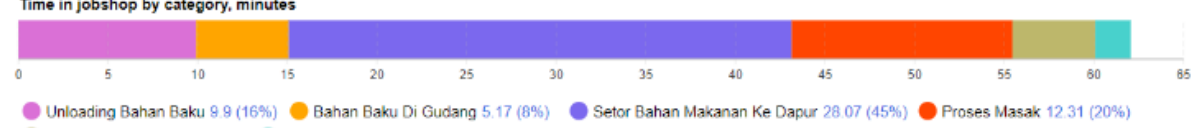

Peyajian Makanan 4.62 (7\%) Santri Makan $1.99(3 \%)$

\section{d. Kondisi 2: Apabila terdapat 2 tukang angkut dengan 1 juru masak}

Metrics

Time in jobshop by category, minutes

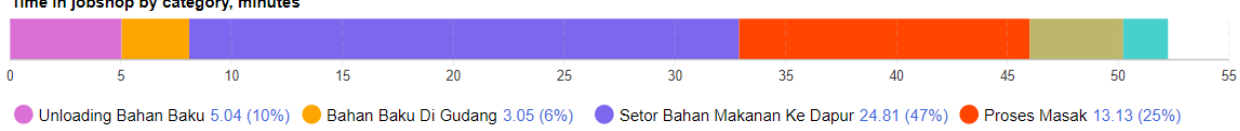

Peyajian Makanan $4.21(8 \%)$ Santri Makan $2.02(4 \%)$

e. Kondisi 3: Apabila terdapat 1 tukang angkut dengan 2 juru masak

Metrics

Time in jobshop by category, minutes

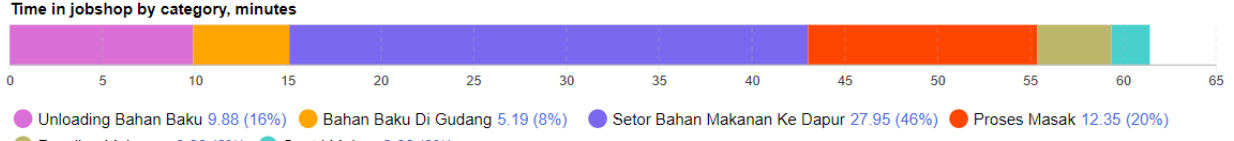

Peyajian Makanan 3.98 (6\%) Santri Makan 2.08 (3\%)

\section{f. Kondisi 4 : Apabila terdapat 2 tukang angkut dengan 2 juru masak}

Metrics

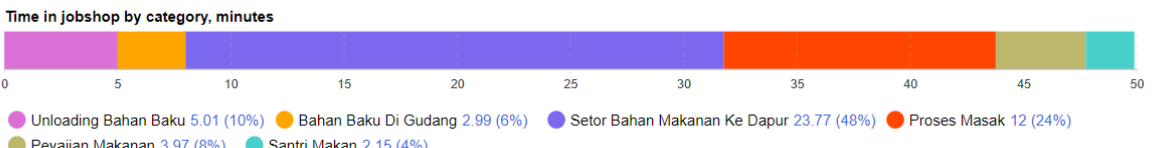

Berdasarkan metrics di atas dengan 4 kondisi yang berbeda didapatkan hasil bahwa : 
a. Terdapat percepatan waktu unloading bahan baku makanan apabila terdapat 2 tukang angkut, dibuktikan dengan kondisi 2 dan kondisi 4 dimana waktu unloading barang lebih cepat dibandingkan kondisi 1 dan 3 dengan hanya satu tukang angkut (bar ungu)

b. Terdapat percepatan angkutan dari inventory ke dapur masak dibuktikan dengan sedikitnya bahan baku di gudang (bar kuning) apabila terdapat 2 tukang angkut.

c. Proses memasak (bar jingga) dipengaruhi oleh banyaknya bahan makanan yang dintarkan ke dapur (bar biru)

d. Terdapat percepatan waktu dalam proses memasak apabila terdapat 2 juru masak.

e. Terdapat waktu yang cukup banyak untuk makan santri apabila menggunakan kondisi 4 dimana terdapat 2 tukang angkut dan 2 juru masak.

\section{SIMPULAN}

Berdasarkan hasil pembahasan pada penelitian ini dapat diambil kesimpulan sebagai berikut:

a. Terdapat 2 fase dari 5 fase pada metode BPI yang digunakan dalam penelitian ini yaitu organizing for improvement dan understanding the process.

b. Dengan dua fase tersebut dapat diketahui alur proses bisnis pondok pesantren pada standar 8 : Penyediaan dan persiapan makanan dan minuman dan rekomendasi perbaikannya untuk selanjutnya dapat dilakukan simulasi proses bisnisnya.

c. Terdapat percepatan waktu unloading bahan baku makanan apabila terdapat 2 tukang angkut

d. Terdapat percepatan angkutan dari inventory ke dapur masak apabila terdapat 2 tukang angkut.

e. Terdapat 4 kondisi yang disimulasikan dan diperoleh hasil bahwa kondisi 4 yaitu dengan 2 tukang angkut dan 2 juru masak adalah kondisi paling optimal dalam proses bisnis pondok pesantren pada standar 8 : Penyediaan dan persiapan makanan dan minuman.

\section{DAFTAR PUSTAKA}

[1] Davenport, Thomas H., "Process Innovation : Reengineering Work Through Information Technology", Harvard Business School Press , 1995.

[2] Greasley A. and Barlow S., "Using simulation modelling for BPR: Resource allocation in a police custody process", International of Operations \&Production Management, Vol, 18, pp 978-988, Oktober 1998.

[3] Harrington, H.J., "Business Process Improvement", New York: McGraw-Hill, Inc, 1991.

[4] Mathias, Weske., "Business Process Management: Concepts, Languages, Architectures", Berlin, Germany: Springer, 2007.

[5] Nasir, Ridwan., "Mencari Tipologi Format Pendidikan Ideal Pondok Pesantren di Tengah Arus Perubahan", Yogyakarta, Pustaka Pelajar, 2005. 
Jurnal Riset Sistem Informasi Dan Teknik Informatika (JURASIK) Volume 5 Nomor 1 Februari, pp 138-146 ISSN: 2527-5771/EISSN: 2549-7839

http://tunasbangsa.ac.id/ejurnal/index.php/jurasik

[6] Ray J.P., Vlatka, H., and George M. G., "Simulation Modelling Of Business Processes", Brunel University, Department of Information Systems and Computing, 1998.

[7] Sharp, A. dan McDermott, P., "Workflow Modeling : Tools for Process Improvement and Application Development", Artech House, 2001.

[8] Sa'ud, U.S., "Penerapan Simulasi Animasi, Bina Sarana, Indonesia, 2005.

[9] Zamakhsyari, Dhofier., "Tradisi Pesantren, Studi Tentang Pandangan Hidup Kyai", Jakarta: LP3ES, 1994. 